\title{
Spectrum of ovarian tumours- a five year study
}

\author{
Narang Sanjeev ${ }^{1}$, Singh Anjali ${ }^{1}$, Nema Shrikant ${ }^{1}$, Karode Rahul ${ }^{1}$ \\ ${ }^{I}$ Department of Pathology, Index Medical College and Research Centre, Indore, India
}

\section{Keywords: \\ Benign; \\ Germ cell; \\ Malignant; \\ Sex cord-stroma; \\ Surface epithelial}

\begin{abstract}
Background: Ovarian tumor is the seventh most common cause of cancer related deaths in female. The aim of this study is to find the, morphological and clinicopathological correlation, gross, histological pattern, and incidence of age distribution of ovarian tumors.
\end{abstract}

Materials and Methods: This retrospective and prospective study was carried out from January 2011 to December 2015. The diagnosis was confirmed by histopathological examination using hematoxylin and eosin stain. Special stains and immunohistochemistry were carried out whenever needed.

Results: Out of total 158 cases, $62.65 \%$ were benign, $3.79 \%$ were borderline, and $33.55 \%$ were malignant. Histologically, surface epithelial tumors were the most common (74.06\%) followed by germ cell tumours $(15.82 \%)$ and sex cord-stromal tumors (10.12\%).Benign tumors were mostly seen in age group of 20-40 years, borderline $21-40$ years, and malignant $50-80$ years.

Conclusion: Tumors originating from surface epithelium are the most common and their malignant counterparts are more frequent in the elderly age group.

\section{Correspondence:}

Dr. Anjali Singh, MBBS, MD

Assistant Professor, Department of Pathology,

Index Medical College and Research Centre,

206, Bairathi colony no.2 Indore, Madhya Pradesh, India

ORCID ID: 0000-0002-4075-9180

Email: dranjali.ind1940@gmail.com

Reveived : May 28th, 2017; Accepted : July 6th, 2017; Published : September 1, 2017

Citation: Narang S, Singh A, Nema S, Karode R. Spectrum of ovarian tumours- a five year study. J

Pathol Nep 2017;7: 1180-3.doi: 10.3126/jpn.v7i2.18002

Copyright: This is an open-access article distributed under the terms of the Creative Commons Attribution 4.0 International License, which permits unrestricted use, distribution, and reproduction in any medium, provided the original author and source are credited.

\section{INTRODUCTION}

Ovarian cancer is the most lethal gynecological malignancy and ranks overall seventh most common cause of cancer. ${ }^{1}$ Among women worldwide and in India it is comprising $8.7 \%$ of cancer in different parts of country. ${ }^{1,2}$ The complex anatomy of ovary and its peculiar physiology with constant cyclic changes from puberty to menopause gives rise to a number of cell types. ${ }^{3}$ The histogenesis of ovarian tumours revolves around the four main components namely Surface epithelium, Germ cell, Sex cord and Specialized ovarian tumours. ${ }^{4}$ Ovarian tumours have a wide spectrum of clinical and morphological features. Ovary being an intra-abdominal organ, diagnosis of ovarian tumours is after late. Among all the ovarian neoplasm about $80 \%$ are benign having cystic solid or mixed characteristics. ${ }^{5}$ The remaining $20 \%$ of these tumours are malignant in nature leading to fatal prognosis. ${ }^{6}$ Women between $65 \& 84$ years of age have ovarian cancer incidence rates 2.3 times higher than younger women. Peak incidence of invasive epithelial ovarian cancer is 50-60 years 
of age. About $30 \%$ ovarian neoplasms in postmenopausal women are malignant. Whereas only about $7 \%$ of ovarian epithelium tumours in the premenopausal women are frankly malignant. ${ }^{7}$ Ovarian tumours are difficult to detect until they are advanced in stage or size, as symptoms are vague and insidious. Identification of various histological patterns of ovarian tumours is important for diagnosis as well as programs. ${ }^{8}$ The purpose of this study was to access the incidence morphological and clinicopathological correlation, gross, histological pattern and incidence of age distribution of ovarian tumours in Indore region.

\section{MATERIALS AND METHODS}

The present retrospective and prospective 5 years study was carried out in the department of pathology, Index medical college Hospital and research Centre, Indore, M.P., India. Permission from the Institutional Review Board was obtained. In the retrospective cases (Jan 2011 to Dec 2011) history and clinical features were collected from record section of the hospital. Gross finding were noted from histopathology records. All paraffin blocks were cut freshly and stained with routine H\&E stain. In prospective cases (Jan 2012 to Dec 2015) specimen received were studied thoroughly to note the gross findings. Sections were taken from representative areas and subjected to routine processing. Paraffin blocks were prepared. Sections were cut 3 to 5 micron thickness and stained with H\&E stain. Special stains like Periodic acid Schiff stain (PAS), Reticulin and immunohistochemistry (IHC) were carried cut whenever needed. All the data were analyzed using Microsoft Excel.

\section{RESULTS}

A Total 158 cases of ovarian tumours were studied at the department of Pathology, Index Medical College, Indore, from January 2011 to December 2015. In this study 99 cases $(62.65 \%)$ were benign, 53 cases $(33.55 \%)$ were malignant and 6 cases $(3.79 \%)$ were borderline tumours.

Histologically surface epithelial tumours were the most common tumours, found in 117 cases $(74.06 \%)$, followed by Germ cell tumours seen in 25 cases $(15.82 \%)$ and sex cord stromal tumours found in 16 cases $(10.12 \%)$ (Table 1). The most common epithelial tumours were Serous tumours $(\mathrm{n}=62 ; 39.24 \%)$, followed by mucinous tumours seen in 40 cases $(25.32 \%)$, Brenner tumours $(\mathrm{n}=6 ; 3.80 \%)$. Endometroid tumour was found in 5 cases $(3.16 \%)$. Out of 25 Germ cell tumours benign cystic teratoma was the most common type, accounting for 15 cases $(8.62 \%)$ and among 16 cases of Sex cord stromal tumours, the most common tumour was Fibroma seen in 10 cases (6.32\%). The commonest presenting symptom was lump in abdomen comprising 88 cases $(55.7 \%)$, followed by pain in abdomen accounting for 70 cases $(44.3 \%)$.
Maximum cases of benign neoplasms were seen between the age group of 20-40 years, whereas malignant tumours were seen after the age of 50 years. The youngest patient was a 2 year old girl with sex cord stromal tumour and the oldest was 80 years old with serous cystadenocarcinoma and peak incidence of benign tumours was found between 21-30 years of age.

Right sided ovarian tumours, 92 cases $(58.2 \%)$ were more common than the left sided tumours seen in 56 cases $(35.4 \%)$ and 10 cases $(6.3 \%)$ were bilateral in that 6 were benign and 4 were malignant. Among all tumours, Mucinous cystadenoma was largest tumour measuring $30 \times 25 \times 17 \mathrm{~cm}$ in size. Most of the tumours were cystic $(\mathrm{n}=110 ; 69.62 \%)$. Almost all benign tumours were cystic. Among them 90 tumours were (56.96\%) benign, 14(8.86\%) were malignant and 6 cases $(3.79 \%)$ were borderline. Serous cystadenocarcinoma $(12.02 \%)$ was the most common among malignant tumours.

\section{DISCUSSION}

A total of 158 cases with ovarian tumours were studied in which 99 cases $(62.65 \%)$ were benign, 6 cases $(3.79 \%)$ were borderline and 53 cases $(33.55 \%)$ were malignant. Histologically Surface epithelial tumours were the most common 117 cases (74.06\%), followed by Germ cell tumours, 25 cases $(15.82 \%)$ and Sex cord stromal tumours, 16 cases $(10.12 \%)$.

Benign tumours were mostly seen in the age group of 21-40 years, borderline 21-50 years and malignant more than 50 years. Peak incidence of benign tumours was found between 21-30 years.

In our study, the most common ovarian tumours were Surface epithelial tumours comprising $74.06 \%$, followed by Germ cell tumours comprising $15.82 \%$ and Sex cord stromal tumours comprising $10.12 \%$.Similar observations were made by Swami and Satyanarayana ${ }^{9}$, Gupta et $\mathrm{al}^{10}$ and Pradhan A et al. ${ }^{11}$ The most common epithelial tumour were Serous cystadenoma followed by Mucinous cystadenoma and most common Germ cell tumour was benign cystic teratoma seen in 15 cases. Similar results have been reported by Yasmin et al. ${ }^{12}$ In our study the most common complaint of patients was lump in abdomen in 88 cases $(85.7 \%)$ followed by pain in lower abdomen, about 70 cases $(44.3 \%)$. These findings are in concordance with those of a study carried out by Pradhan A et al. ${ }^{11}$

Majority of benign tumours occurred in the age group of 20-40 years in present study and malignant tumours were more common in older age. This is in agreement with the results of a study done by Jha and Karki et $\mathrm{al}^{13}$ as well as Shah and Hishikar et al. ${ }^{14}$ In our study 10 cases $(6.3 \%)$ of bilateral ovarian tumours were seen. This incidence is lower 


\begin{tabular}{|c|c|c|c|c|}
\hline $\begin{array}{l}\text { Sr. } \\
\text { No. }\end{array}$ & $\begin{array}{l}\text { Histological type } \\
\text { of tumours }\end{array}$ & $\begin{array}{l}\text { Number of } \\
\text { cases }\end{array}$ & $\begin{array}{l}\text { Percentage } \\
(\%)\end{array}$ & $\begin{array}{l}\text { Overall } \\
(\%)\end{array}$ \\
\hline 1. & $\begin{array}{l}\text { Surface epithelial } \\
\text { tumours }\end{array}$ & 117 & 100 & 74.06 \\
\hline \multirow[t]{4}{*}{ A. } & Serous tumours & 62 & 53.00 & 39.24 \\
\hline & Benign & 40 & 34.19 & 25.32 \\
\hline & Borderline & 03 & 2.56 & 1.90 \\
\hline & Malignant & 19 & 16.25 & 12.02 \\
\hline \multirow[t]{4}{*}{ B. } & Mucinous tumours & 40 & 34.19 & 25.32 \\
\hline & Benign & 25 & 21.37 & 15.82 \\
\hline & Borderline & 03 & 2.56 & 1.90 \\
\hline & Malignant & 12 & 10.26 & 7.60 \\
\hline C. & $\begin{array}{l}\text { Endometrioid } \\
\text { tumours }\end{array}$ & 05 & 4.26 & 3.16 \\
\hline D. & $\begin{array}{l}\text { Clear cell adeno } \\
\text { carcinoma }\end{array}$ & 02 & 1.71 & 1.27 \\
\hline \multirow[t]{3}{*}{ E. } & $\begin{array}{l}\text { Transitional cell } \\
\text { tumours }\end{array}$ & 08 & 6.84 & 5.07 \\
\hline & Brenner tumours & 06 & 5.13 & 3.80 \\
\hline & $\begin{array}{l}\text { Transitional cell } \\
\text { carcinoma }\end{array}$ & 02 & 1.71 & 1.27 \\
\hline \multirow[t]{3}{*}{2.} & $\begin{array}{l}\text { Sex cord stromal } \\
\text { tumours }\end{array}$ & 16 & 100 & 10.12 \\
\hline & Fibroma & 10 & 62.5 & 6.32 \\
\hline & $\begin{array}{l}\text { Granulosa cell } \\
\text { tumours }\end{array}$ & 06 & 37.5 & 3.80 \\
\hline \multirow[t]{6}{*}{3.} & Germ cell tumours & 25 & 100 & 15.82 \\
\hline & Dysgerminoma & 03 & 12.0 & 1.90 \\
\hline & Yolk sac tumours & 02 & 8.0 & 1.26 \\
\hline & Mature Teratoma & 15 & 60.0 & 9.50 \\
\hline & Immature teratoma & 03 & 12.0 & 1.90 \\
\hline & $\begin{array}{l}\text { Mixed germ cell } \\
\text { tumours }\end{array}$ & 02 & 8.0 & 1.26 \\
\hline
\end{tabular}

than $13.04 \%$ and $8.3 \%$ reported by Jha and Karki et $\mathrm{al}^{13}$ and Kanthikar et al. ${ }^{15}$

The largest tumour found in the present study was Mucinous cystadenoma measuring $30 \times 25 \times 17 \mathrm{~cm}$ in size. Similar observation was noted by Zaman et $\mathrm{al}^{16}$ who reported a case of mucinous cystadenoma of $27 \mathrm{~cm}$ in diameter. Benign tumours were mostly cystic $(56.96 \%)$ in consistency in our study, which was similar to the results of (44.78\%) Kanthikar et $\mathrm{al}^{15}$ and malignant tumours were solid in consistency. Similar observation has been reported by kanthikar et al. ${ }^{15}$

Among the Surface epithelial tumours Serous tumours were the most common tumours accounting 62 cases $(39.24 \%)$ which is comparable to $50 \%$ as reported by Kanthikar et al. ${ }^{15}$ Mucinous tumours were seen in $25.32 \%$ cases of all ovarian tumours which is more than the observation of Jha and Karki et $\mathrm{al}^{13}$ and Kanthikar et $\mathrm{al}^{15}$ which were showing $16.8 \%$ and $10.10 \%$. Five cases $(3.16 \%)$ of Endometrioid carcinoma noted in our study which is similar to observation of Zaman et $\mathrm{al}^{16}$ which was showing 6 cases,3.81\% and lower than the observation of Ahmed et al ${ }^{17}$ which was showing $7.73 \%$.

In our study 6 cases $(3.80 \%)$ of Granulosa cell tumours were seen which was comparable to the study ( $n=9 ; 5.80 \%)$ conducted by Zaman et al. ${ }^{16}$ Fibroma were seen in $6.3 \%$ of cases in present study. This observation was similar to the observation of Kanthikar et $\mathrm{al}^{15}$ who demonstrated fibromas in 4.28 percent.

Yolk sac tumours were seen in two cases between the age of 40-50 years, acounting for $1.27 \%$ of all ovarian tumours which is comparable to the result observed by and Zaman et $\mathrm{al}^{16}$ and Ahmed et $\mathrm{al}^{17}$, who reported yolk sac tumour in $0.64 \%$ and $3.44 \%$ respectively.

Teratoma was the most common Germ cell tumour found in our study contributing 18 cases $(11.40 \%)$ of all ovarian tumours which is comparable to the results observed in studies carried out by Yasmin et $\mathrm{al}^{12}$ and Zaman et $\mathrm{al}^{16}$ which were showing $18 \%$ and $19.35 \%$.However Jha and Karki ${ }^{13}$ and Ahmed et al ${ }^{17}$ found a higher percentage i.e $40.3 \%$ and $76.72 \%$ cases respectively.

\section{CONCLUSION}

It is concluded from this study that on morphological grounds, tumors originating from surface epithelium are the most common and their malignant counterparts are more frequent in the elderly age group. Therefore, it is suggested that such patients should be examined and treated promptly to reduce the associated morbidity and mortality.

\section{ACKNOWLEDGEMENTS}

The authors acknowledge the help given by Dr. Anil Kapoor and Dr. Abhishek Rathore in the preparation of the manuscript. We would also like to thank Dr. Parul Dargar and Dr. Priyanka Sachdev, Department of Pathology, Index Medical College, Indore (M.P.), India for assisting in the data collection for this study.

\section{Conflict of interest: None}

\section{REFERENCES}

1. Basu P, De P, Mandal S, Ray K, Biswas J. Study of 'patterns of care' of ovarian cancer patients in a specialized cancer institute in Kolkata, eastern India. Indian J Cancer 2009;46:28-33. Crossref 
2. Mondal SK, Banyopadhyay R, Nag DR, Roychowdhury S, Mondal PK, Sinha SK. Histologic pattern, bilaterality and clinical evaluation of 957 ovarian neoplasms: a 10-year study in a tertiary hospital of eastern India. J Cancer Res Ther 2011;7:433-7. Crossref

3. Prabhakar B.R Maingi K. Ovarian tumours - Prevalence in Punjab. Indian J Pathol and Microbiol 1989;32:276-81. Crossref

4. Rosai J. Female reproductive system In: Ackerman's Surgical Pathology, 8th edition. Mosby - Year book Inc. Newyork; 1996. p1473-539.

5. Tortulero L, Mitchell FM, Rhodes HE. Epidemidology and screening of ovarian cancer. Obstet Gynaecol Clin North Amer 1994;21:63-75.

6. Rashid S, Sarwas G, Ali A. A clinicopathological study of ovarian cancer. Mother Child 1998;36:117-25.

7. Berek JS. Ovarian and fallopian tube cancer. In: Berek \& Novak's Gynecology, 14th edn. Wolters Kluwer Health: India; 2007. pp1457-547.

8. Mankar DV, Jain GK. Histopathological profile of ovarian tumours: A twelve year institutional experience. Muller J Med Sci Res 2015;6:107-11. Crossref

9. Swamy GG, Satyanarayana N. Clinicopathological analysis of ovarian tumors: a study on five years samples. Nepal Med Coll J 2010;12:221-3. Crossref
10. Gupta N, Bisht D, Agarwal AK, Sharma VK. Retrospective and prospective study of ovarian tumors and tumor-like lesions. Indian J Pathol Microbiol 2007;50:525-7. Crossref

11. Pradhan A, Sinha AK, Upreti D. Histopatological pattern of ovarian tumours at BPKIHS. Health Renaissance 2012;10;8797. DOI: Crossref

12. Yasmin S, Yasmin A, Asif M. Clinicohistological pattern of ovarian tumors in Peshawar region. J Ayub Med Coll Abbottabad 2008;20:11-3. Crossref

13. J ha R, Karki S. Histological pattern of ovarian tumors and their age distribution. Nepal Med Coll J 2008;10:81-5. Crossref

14. Shah S, Hishikar VA. Incidence and management of ovarian tumours. Bombay Hospital J 2008;50:30-3.

15. Kanthikar SN, Dravid NV, Deore PN, Nikumbh DB, Suryawanshi KH.Clinico- histopathological analysis of neoplastic and non-neoplastic lesions of the ovary: a 3-year prospective study in Dhule, North Maharashtra, India. J Clin Diagn Res 2014;8:FC04-7.

16. Zaman S, Majid S, Hussain M, Chughtai O, Mahboob J, Chughtai S. A retrospective study of ovarian tumours and tumour-like lesions. J Ayub Med Coll Abbottabad 2010;22:104-8. Crossref

17. Ahmad Z, Kayani N, Hasan SH, Muzaffar S, Gill MS. Histological pattern of ovarian neoplasma. J Pak Med Assoc 2000;50:416-9. Crossref 